\title{
Nieznośne piękno rękopisu
}

Rękopis uświadamiał mi zawsze istnienie dziwnej, niejasnej pozycji ontologicznej tego typu zapisu tekstu, którą jedynie antybinarna, chwytająca ulotne stany pośrednie terminologia Leśmianowska mogłaby najbliżej oddawać. Rękopis nie znosi opozycji. Jest on paradoksalnie zarówno brudno-, jak i czystopisem (zostanie przepisany „na czysto” na maszynie, rozprzestrzeni się w setkach wydruków komputerowych albo będzie trwał jako jedyny, niepowtarzalny ślad istnienia Autora, potwierdzając wyjątkowość jego miejsca na ziemi), należy do sfery ciała (pismo utrwala nacisk ręki, pracę ciała zaangażowanego w pisanie), ale i wykazuje związki z duchowością (ujawnia stany psychiczne piszącego, nerwowość, spokój lub rozchwianie emocjonalne). Rękopis stoi na pograniczu sztuk, zwłaszcza plastyki, literatury i teatru. Kolorowe linie atramentu czy tuszu, rozplanowanie tekstu $\mathrm{w}$ przestrzeni, czasem ozdobne duże litery, dopiski, glosy, puste lub zapisane przestrzenie papieru itp. tworzą specyficzną sceno-grafię rękopiśmiennego tekstu. Rękopis może być oglądany jak obraz, równocześnie jak teatr, który epatuje dynamiczną grą autorskiego gestu utrwalonego w sile i jakości zapisu, każący, zwłaszcza u twórców malarzy i plastyków, przenosić linię i kształt sygnatury na motywy obrysów tworzących obraz. W moim odczuciu rękopis jest śladem (w znaczeniu Derridiańskim) płynnie przekazującym swoistą grę powstawania i wymazywania, w pozornie stabilnej przestrzeni dokonujący zapisu dynamiki przepływalności, pamięci wahania (skreślenia, wymazania, korekcje, palimpsesty, zapisy na odwrocie, nieśmiałe wcinanie tekstu uzupełnień, wzięcia $\mathrm{w}$ nawias itp.) i siły decyzji (podkreślenia, pogrubienie liter, zwiększony nacisk ręki prowadzącej pismo, obrysowania, ujęcia w ramki itp.). Rękopisy są materialnym przedmiotem (można je podrzeć, zalać, zdrapać, porysować, zmiąć i unicestwić), ale też stanowią synonim niezniszczalności myśli, trwania na przekór materii, wbrew upływowi czasu, przeciw cenzurze polityki, czasu, pamięci („rękopisy nie płoną"). W takim sensie także są śladem - wrażeniem trwałego dotknięcia tajemnicy (rysu niepowtarzalności człowieka mimo ułomności nietrwałej materii).

Rękopisy ujawniają upływ czasu - jako materie żółkną, bledną, szarzeją, kruszą się wraz ze starzeniem się papieru, zagięciem i rysą na fotografii w miejscu dedykacji i równocześnie trwają, wpływając na aktualne odczytania dzieła. Nowo odkryte lub przeczytane raz jeszcze zmieniają niekiedy sens całych utworów, a nawet w innym świetle pokazują dotychczasową twórczość artystów. Niektóre fragmenty rękopisów Juliusza Słowackiego zestawione nagle z rękopisami wierszy Tadeusza 
Różewicza w jakimś nieoczekiwanym układzie zbliżają nagle twórców do siebie. To my, nasze spojrzenie łączy lub rozdziela, lecz przez to jesteśmy w stanie wciąż na nowo uruchamiać teksty dawne i współczesne. Gdy czynimy tak z tekstami wydanymi, ujednoliconymi przez druk i powielenie, mamy świadomość interpretacji podjętej przez wydawcę. Gdy pochylamy się nad rękopisem, doznajemy wrażenia kontaktu bezpośredniego $\mathrm{z}$ osobą. Stajemy często zawstydzeni dokonującym się aktem podejrzenia - odkrycia wahań i bezradności, pomyłki, błędu, genialności. Do rękopisów nie można mieć obojętnego stosunku. Mają one emocjonalną wartość podobną do tej, z którą traktujemy przechowywane pieczołowicie zapiski naszych bliskich - listy, wyznania, dedykacje, życzenia, polecenia itp. Rękopisy znoszą, chciałoby się powiedzieć, podział na to, co literackie $\mathrm{i}$ to, co pozaliterackie. Zacieraja granice, niweluja dystans. Komputerowy zapis jest gotowy w zdecydowanej przez Autora formie, ukrywa skrzętnie zmiany decyzji, zaciera uświadomione pomyłki. Niezastąpiony przycisk delete rozwiązuje wiele problemów. Tekst doskonale czysty nie może się rozchwiać, wciąć, wrysować, nadpisać, wykrzywić w sposób dziki, niekontrolowany. Zapis ludzkiej ręki będzie zawsze ułomny i poprzez tę swoją niedoskonałość równocześnie znacznie bogatszy.

Stąd nie wyobrażam sobie dedykacji napisanej na komputerze i wklejonej komuś do książki. Akt dedykacji ma charakter teatralnego doznania - oto jestem obecny, mówię wprost do ciebie jako widza, piszę słowa własną ręką świadom, że mogę się za chwilę pomylić, nie utrzymać prosto $\mathrm{w}$ linii zapisu, może zabraknąć atramentu w piórze. Te wady „niedopisania” są wpisane w dedykowanie jako potencjalny akt porażki. Nie można już jej zmienić, chyba że wyrzucimy cały egzemplarz. Trzymam przed sobą książkę jednego $\mathrm{z}$ wielkich nieżyjących poetów z dedykacją pisaną drżącą ręką na kilka dni przed śmiercią. Jej tekstu nigdy do końca nie umiałam dokładnie odczytać, ale obok, jakby z niej, wyrasta rysunek róży i drżenie kreski zmienia się nagle w doskonałość zarysu rośliny z lekko nierównymi brzegami liści, kolcami wyrastającymi z łodygi, postrzępieniem płatków rozchylającego się kwiatu. Nazywam ją do dziś dedykacją z różą.

Zbierajmy rękopisy, ich historie są dziejami czasu i ludzi, nastrojów i czynów, myśli i decyzji - odwołują się do kategorii estetycznych związanych z niepewnością i przemijalnością. Czytajmy rękopisy - one są najbardziej uchwytnym początkiem tekstu. Praca nad rękopisami w połączeniu z całym dziełem twórcy buduje światy poprzez próbę dotyku i uchwycenia wciąż wymykającej się nam istoty procesu twórczego. Nieznośna piękność rękopisu określa świat przejścia między początkowym słowem i jednostkowym wymiarem bytu.

Anna Krajewska 